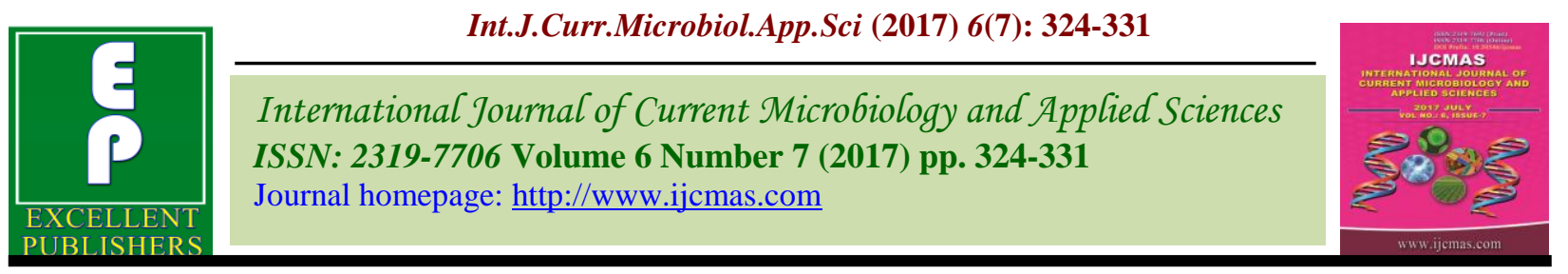

Original Research Article

https://doi.org/10.20546/ijcmas.2017.607.038

\title{
Genetic Analysis of Promising Crosses and Good Combiners for Developing New Genotypes in Groundnut (Arachis hypogaea L.)
}

\author{
B.D. Waghmode ${ }^{1 *}$, A.B. Kore ${ }^{2}$, V.C. Navhale ${ }^{1}$, N.G. Sonone ${ }^{1}$ and B.L. Thaware ${ }^{2}$ \\ ${ }^{1}$ Agricultural Research Station, Shirgaon, Ratnagiri - 415 629, Maharashtra, India \\ ${ }^{2}$ Department of Agricultural Botany, Collage of Agriculture, Dapoli-415 712, Maharashtra, India \\ *Corresponding author
}

\section{A B S T R A C T}

The experiment was undertaken to study the combining ability for yield and its attributing traits in groundnut. The experimental material consisted of four lines and five testers

Keywords

Groundnut,

Combining ability,

Additive gene

action, Non-

additive gene

action.

Article Info

Accepted:

04 June 2017

Available Online:

10 July 2017 mated in L X T mating design. Analysis of variance for combining ability for the traits viz., plant height, number of pods plant ${ }^{-1}$, dry pod yield plant ${ }^{-1}$, dry haulm yield plant ${ }^{-1}$, hundred kernel weight, shelling percentage, sound mature kernel, days to maturity, oil content were highly significant for female, male and female vs. male parents. Protein content was highly significant for female and female vs. male and positive but non-significant for male. Among the male parent, TAG 24 recorded higher mean performance for most of the characters and identified as good combiner for some of traits while as among the female line RHRG 6083 recorded higher mean performance and identified as good combiner with significant gca effects for most of the characters, could be utilized for further hybridization programme. Higher magnitude of sca and low value of gca effects indicated influence of non-additive gene action. On the basis of per se performance and combining ability the hybrids viz., RHRG 6083 X TAG 24, Konkan Gaurav X KDG 209 and RHRG 6083 X RTNG 29 were found to be the most promising combinations in most of the yield contributing traits and may be exploited in further plant breeding programme or identification of transgressive sergeants from the further generations.

\section{Introduction}

Groundnut (Arachis hypogaea L.) is an important oilseed crop and grain legume grown worldwide. Its seeds are rich source of edible oil (43-55\%) and protein (25 to $28 \%)$. Its cake is used as feed or for making other food products and haulms provide quality fodder. India has a largest area under groundnut in the world but productivity of groundnut has been rather low $(1712 \mathrm{~kg} / \mathrm{ha})$ when compared with the world (1819 kg/ha). The productivity is restricted by drought, low inputs by small holders and marginal farmers in dry land areas, high incidence of soil borne, foliar fungal and virus diseases and attack by certain insect pests. Groundnut production in India is mostly concentrated in six states Gujarat, Andhra Pradesh, Tamil Nadu, Karnataka, Maharashtra and Rajasthan.

In Maharashtra state it is cultivated on area of 1.96 lakh hectares with productivity of 1163 $\mathrm{kg} / \mathrm{ha}$ during kharif season and 0.71 lakh ha area with $1366 \mathrm{~kg} / \mathrm{ha}$ productivity during rabi season 2013-14. In Konkan region during kharif groundnut is grown on 8400 hectares area with productivity of $1130 \mathrm{~kg} / \mathrm{ha}$ while, it 
is cultivated on more than 5000 ha area with $1827 \mathrm{~kg}$ /ha during rabi season.

In any breeding programme the proper choice of parents based on their combining ability is a pre requisite. This not only provides necessary information regarding the choice of parents but also simultaneously illustrate the nature and magnitude of gene action involved in the expression of desirable traits. Accordingly, the present investigation was undertaken to have an idea of the nature of gene action for dry pod yield and other important attributes in groundnut. Several biometrical methods are available for studying the combining ability and gene action. Hence the LxT gives a fairly good idea of both general and specific combining abilities of parents and hybrid combinations respectively. The study reported here was designed to gather information on the genetics of the characters studied and on the extent of combining ability for yield and its yield attributing traits in groundnut.

\section{Materials and Methods}

The material consisted of four females (lines) (RHRG 6083, TG 37A, Konkan Gaurav and RHRG 1225) and five males (testers) (RTNG 29, KDG 209, TAG 24, ICG 2630 and JL 777). The crosses were effected to produce twenty $\mathrm{F}_{1} \mathrm{~s}$. These $\mathrm{F}_{1} \mathrm{~s}$ along with their parents were sown in Randomized Block Design (RBD) with three replications with the spacing of $30 \mathrm{~cm} \mathrm{X} 10 \mathrm{~cm}$ during August 2015 to November 2015 at Experimental Farm of Agricultural Research Station, Shirgaon (Ratnagiri). Data were recorded on five randomly selected plants per replication from each treatment. Thirteen characters viz., days to 50 per cent flowering, plant height, number of primary branches plant ${ }^{-1}$, number of pods plant ${ }^{-1}$, number of kernels pod ${ }^{-1}$, dry pod yield plant ${ }^{-1}$, dry haulm yield plant ${ }^{-1}, 100$ kernel weight, shelling percentage, sound mature kernel, days to maturity, oil content and protein content were recorded as per standard procedures. The data were subjected to line $\mathrm{X}$ testers' analysis according to Kempthorne (1957).

\section{Results and Discussion}

The analysis of variance (Table 1) indicated significant differences for all the characters except days to $50 \%$ flowering, number of primary branches per plant and number of kernels per plant among parents as well as hybrids indicating that the parents chosen and their hybrids exhibited considerable variability for almost all the characters. Higher magnitude of variance in case of hybrids as compared to parents has been observed for many characters like plant height, number of pods plant ${ }^{-1}$, dry pod yield plant $^{-1}$, dry haulm yield plant ${ }^{-1}, 100$ kernel weight, shelling percentage, sound mature kernels, days to maturity, oil and protein content indicating the presence of heterosis for these characters. However, variance due to females, males and female $\mathrm{X}$ male were significant for almost all the characters studied except days to $50 \%$ flowering, number of primary branches plant ${ }^{-1}$ and number of kernels pod $^{-1}$. The results indicate the presence of considerable variability among the parents selected for crossing programme and hybrids obtained from them. Hence, it is possible to select desirable hybrids with high yield. The parents were characterized for their ability to transmit desirable genes to their progenies (Table 2). Female RHRG 6083 was good general combiner for number of pods plant ${ }^{-1}$, dry pod yield plant $^{-1}$, and dry haulm yield plant ${ }^{-1}$. Among males ICG 2630 was found to be good general combiner for plant height and days to maturity. All male parents used for hybridization programme were showed average combining ability for almost all the characters studied except TAG 24 for plant height and KDG 209 and JL 777 for days to maturity. 
Table.1 ANOVA for combining ability for 13 growth and yield related traits in groundnut

\begin{tabular}{|c|c|c|c|c|c|c|c|c|c|c|c|c|c|c|}
\hline Source & DF & DFF & PH & NPB & NPPP & NKPP & DPY & DHY & HKW & SH & SMK & DM & OC & $\mathbf{P C}$ \\
\hline Female & 4 & 1.433 & $57.672 * *$ & 0.762 & $16.076 * *$ & 0.006 & $26.916 * *$ & $23.950 * *$ & $17.892 * *$ & $37.634 * *$ & $9.660 * *$ & $123.475^{* *}$ & $39.62 * *$ & $14.01 * *$ \\
\hline Male & 3 & 2.089 & $131.886 * *$ & 1.289 & $76.974 * *$ & 0.002 & $75.604 * *$ & $56.556 * *$ & $181.637 * *$ & $3.808 * *$ & $31.676 * *$ & $698.861 * *$ & $25.34 * *$ & 0.81 \\
\hline $\begin{array}{l}\text { Females } \\
\text { x Males }\end{array}$ & 12 & 1.644 & $73.329 * *$ & 0.41 & $30.883 * *$ & 0.01 & $8.559 * *$ & $20.357 * *$ & $22.114 * *$ & $22.751 *$ & $18.893 * *$ & $48.375^{* *}$ & $21.10 * *$ & $5.08 * *$ \\
\hline Error & 38 & 6.641 & 23.771 & 0.118 & 7.922 & 0.006 & 10.057 & 10.555 & 19.131 & 5.942 & 9.71 & 15.007 & 4.18 & 6.12 \\
\hline
\end{tabular}

* Significant at 5 per cent, ** Significant at 1 per cent,

$\mathrm{DFF}=$ Days to fifty per cent flowering, $\mathrm{PH}=$ Plant Height $(\mathrm{cm}), \mathrm{NPB}=$ Number of Primary Branches ${ }^{-1}, \mathrm{NPPP}=\mathrm{Number}_{\mathrm{of}}$ pods plant ${ }^{-1}$,

$\mathrm{NKPP}=$ number of kernel pod ${ }^{-1}, \mathrm{DPY}=$ Dry pod yield plant $^{-1}(\mathrm{~g}), \mathrm{DHY}=$ Dry haulm weight plant ${ }^{-1}$, HKW $=$ Hundred kernel weight,

$\mathrm{SH} \%=$ Shelling percentage, $\mathrm{SMK}=$ Sound mature kernel, DM= Days to maturity, OC = Oil content $(\%), \mathrm{PC}=\mathrm{Protein}$ content $(\%)$

Table.2 General combining ability effects of parents for yield and yield related traits in groundnut

\begin{tabular}{|c|c|c|c|c|c|c|c|c|c|c|c|c|c|}
\hline Parents & DFF & $\mathbf{P H}$ & NPB & NPPP & NKPP & DPY & DHY & HKW & SH & SMK & DM & OC & $\mathbf{P C}$ \\
\hline \multicolumn{14}{|l|}{ Female } \\
\hline RHRG 6083 & -0.267 & -1.915 & 0.33 & $3.13^{* *}$ & 0.008 & $3.22 * *$ & $2.85^{* *}$ & -0.3 & -0.053 & -1.3 & $3.98 * *$ & -0.5 & -1.26 \\
\hline TG 37A & 0.46 & -2.34 & -0.33 & -0.53 & 0.008 & -1.7 & -1.31 & $-4.44 * *$ & 0.67 & -1.16 & $-9.88 * *$ & $-2.19^{*}$ & -0.22 \\
\hline K.GAURAV & 0.13 & 0.11 & -0.13 & -0.31 & -0.012 & -1.34 & -1.09 & $3.99 * *$ & -0.073 & 0.88 & $5.05 * *$ & -0.95 & 1.1 \\
\hline RHRG 1225 & -0.33 & $4.14 * *$ & 0.13 & $-2.28 *$ & -0.005 & -0.17 & -0.43 & 0.75 & -0.54 & 1.58 & 0.85 & 1.3 & 1.11 \\
\hline SE ( $(+)$ & 0.576 & 1.090 & 0.077 & 0.629 & 0.017 & 0.709 & 0.726 & 0.978 & 0.545 & 0.697 & 0.866 & 0.528 & 0.639 \\
\hline \multicolumn{14}{|c|}{ Male } \\
\hline RTNG 29 & -0.4 & 0.39 & 0.19 & 0.007 & -0.003 & 0.77 & 1.3 & 1.59 & 0.01 & -0.5 & 0.76 & $2.34 *$ & -0.73 \\
\hline KDG 209 & -0.06 & -0.53 & -0.43 & -0.49 & -0.012 & -1.84 & -1.63 & 0.94 & 1.94 & -0.88 & $3.1 * *$ & -1.14 & 0.05 \\
\hline TAG 24 & 0.43 & $2.99 * *$ & 0.053 & 1.8 & -0.028 & 1.1 & 1.31 & -1.09 & -1.6 & 0.94 & $-3.73 * *$ & 0.46 & 0.07 \\
\hline ICG 2630 & -0.23 & $-3.11 * *$ & 0.032 & -1.36 & 0.022 & -1.38 & -1.33 & -0.32 & 1.57 & 0.99 & $-2.98 * *$ & -0.94 & 0.2 \\
\hline JL 777 & 0.26 & 0.26 & 0.15 & 0.04 & 0.022 & 1.35 & 0.35 & -1.11 & -1.92 & -0.54 & $2.85 * *$ & 1.62 & -0.33 \\
\hline SE ( $(+)$ & 0.665 & 1.259 & 0.089 & 0.727 & 0.019 & 0.819 & 0.839 & 1.129 & 0.629 & 0.805 & 1.000 & 0.457 & 0.553 \\
\hline
\end{tabular}

* Significant at 5 per cent, ** Significant at 1 per cent, DFF = Days to fifty per cent flowering, PH = Plant Height $(\mathrm{cm}), \mathrm{NPB}=\mathrm{Number}$ of Primary Branches ${ }^{-1}$,

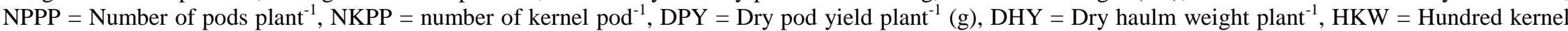
weight, $\mathrm{SH} \%=$ Shelling percentage, $\mathrm{SMK}=$ Sound mature kernel, DM= Days to maturity, OC $=$ Oil content $(\%)$, PC $=$ Protein content $(\%)$ 
Table.3 Summary of general combining ability effect of the parent for different character in groundnut

\begin{tabular}{|c|c|c|c|c|c|c|c|c|c|c|c|c|c|}
\hline Parents & DFF & PH & NPB & NPPP & NKPP & DPY & DHY & HKW & SH & SMK & DM & OC & $\mathbf{P C}$ \\
\hline \multicolumn{14}{|l|}{ Female } \\
\hline RHRG 6083 & A & A & A & G & A & $\mathrm{G}$ & G & A & A & A & $\mathrm{P}$ & A & A \\
\hline TG 37A & A & $\mathrm{A}$ & A & A & $\mathrm{A}$ & A & A & $\mathrm{P}$ & A & A & $\mathrm{G}$ & $\mathrm{P}$ & A \\
\hline Konkan Gaurav & A & A & A & A & A & A & A & G & A & A & $\mathrm{P}$ & A & A \\
\hline RHRG 1225 & A & $\mathrm{P}$ & A & $\mathrm{P}$ & A & A & $\mathrm{A}$ & $\mathrm{A}$ & $\mathrm{A}$ & A & $\mathrm{A}$ & A & A \\
\hline \multicolumn{14}{|l|}{ Male } \\
\hline RTNG 29 & A & A & A & A & A & A & A & $\mathrm{A}$ & A & A & A & $\mathrm{G}$ & $\mathrm{A}$ \\
\hline KDG 209 & $\mathrm{~A}$ & A & A & A & A & A & A & A & A & A & $\mathrm{P}$ & A & A \\
\hline TAG 24 & $\mathrm{~A}$ & $\mathrm{P}$ & A & A & A & A & A & A & A & A & G & A & A \\
\hline ICG 2630 & A & G & A & A & A & A & A & A & A & A & $\mathrm{G}$ & A & A \\
\hline JL 777 & A & A & A & A & $\mathrm{A}$ & A & $\mathrm{A}$ & $\mathrm{A}$ & A & $\mathrm{A}$ & $\mathrm{P}$ & A & A \\
\hline
\end{tabular}

$\mathrm{G}$ = Good parent having significant GCA effects in desirable direction; A = Average parent having either positive or negative but non-significant GCA effects; $\mathrm{P}$ $=$ Poor parent having significant GCA effects in undesirable direction

$\mathrm{DFF}=$ Days to fifty per cent flowering, PH $=$ Plant Height $(\mathrm{cm}), \mathrm{NPB}=$ Number of Primary Branches $^{-1}, \mathrm{NPPP}=\mathrm{Number}$ of pods plant ${ }^{-1}, \mathrm{NKPP}=$ number of kernel pod $^{-1}, \mathrm{DPY}=$ Dry pod yield plant ${ }^{-1}(\mathrm{~g}), \mathrm{DHY}=$ Dry haulm weight plant ${ }^{-1}$, HKW $=$ Hundred kernel weight, SH $\%=$ Shelling percentage, SMK $=$ Sound mature kernel, $\mathrm{DM}=$ Days to maturity, $\mathrm{OC}=$ Oil content $(\%), \mathrm{PC}=$ Protein content $(\%)$ 
Table.4 Promising crosses based on specific combining ability in groundnut

\begin{tabular}{|c|c|c|c|c|c|}
\hline \multirow[t]{2}{*}{ Characters } & \multirow[t]{2}{*}{ Crosses } & \multirow{2}{*}{$\begin{array}{c}\text { SCA } \\
\text { effects } \\
\text { of crosses }\end{array}$} & \multicolumn{2}{|c|}{$\begin{array}{l}\text { GCA effects of } \\
\text { parents }\end{array}$} & \multirow{2}{*}{$\begin{array}{l}\text { SE } \\
(\underline{+)}\end{array}$} \\
\hline & & & $\mathbf{P 1}$ & $\mathbf{P 2}$ & \\
\hline \multirow{3}{*}{ Days to $50 \%$ flowering } & RHRG 6083 X RTNG 29 & -1.07 & A & A & \multirow{3}{*}{1.152} \\
\hline & RHRG 1225 X KDG 209 & -0.67 & A & A & \\
\hline & K.GAURAV X TAG 24 & -0.63 & $\mathrm{~A}$ & $\mathrm{~A}$ & \\
\hline \multirow[t]{3}{*}{ Plant height $(\mathrm{cm})$} & K.GAURAV X ICG 2630 & $-6.34 * *$ & $\mathrm{~A}$ & $\mathrm{G}$ & \multirow{3}{*}{2.180} \\
\hline & RHRG 6083 X KDG 209 & $-5.35 * *$ & A & A & \\
\hline & TG 37A X TAG 24 & $-5.32 * *$ & A & $\mathrm{P}$ & \\
\hline \multirow{3}{*}{$\begin{array}{l}\text { No. of primary branches } \\
\text { plant }^{-1}\end{array}$} & RHRG 1225 X ICG 2630 & 0.56 & A & A & \multirow{3}{*}{0.154} \\
\hline & K.GAURAV X TAG 24 & 0.46 & $\mathrm{~A}$ & $\mathrm{~A}$ & \\
\hline & TG 37A X JL 777 & 0.37 & $\mathrm{~A}$ & $\mathrm{~A}$ & \\
\hline \multirow[t]{3}{*}{ No. of pods plant ${ }^{-1}$} & RHRG 6083 X TAG 24 & $3.82 * *$ & $\mathrm{G}$ & A & \multirow{3}{*}{1.259} \\
\hline & RHRG 6083 X JL 777 & $3.59 * *$ & $\mathrm{G}$ & A & \\
\hline & K.GAURAV X ICG 2630 & $3.43 * *$ & A & $\mathrm{A}$ & \\
\hline \multirow{3}{*}{ No. of kernels pod ${ }^{-1}$} & TG 37A X KDG 209 & 0.09 & $\mathrm{~A}$ & $\mathrm{~A}$ & \multirow{3}{*}{0.034} \\
\hline & K.GAURAV X TAG 24 & 0.06 & A & A & \\
\hline & RHRG 6083 X RTNG 29 & 0.05 & A & A & \\
\hline \multirow[t]{3}{*}{ Dry pod yield plant $^{-1}(\mathrm{~g})$} & RHRG 6083 X TAG 24 & $3.10 * *$ & $\mathrm{G}$ & $\mathrm{A}$ & \multirow{3}{*}{1.418} \\
\hline & K.GAURAV X KDG 209 & $2.37 *$ & $\mathrm{~A}$ & $\mathrm{~A}$ & \\
\hline & RHRG 6083 X RTNG 29 & $2.23 *$ & $\mathrm{G}$ & $\mathrm{A}$ & \\
\hline \multirow{3}{*}{$\begin{array}{l}\text { Dry haulm weight plant }{ }^{-1} \\
\text { (g) }\end{array}$} & RHRG 6083 X TAG 24 & $3.98 * *$ & $\mathrm{G}$ & A & \multirow{3}{*}{1.453} \\
\hline & RHRG 6083 X RTNG 29 & $2.55^{*}$ & $\mathrm{G}$ & $\mathrm{A}$ & \\
\hline & K.GAURAV X KDG 209 & $2.27 *$ & A & $\mathrm{A}$ & \\
\hline \multirow[t]{3}{*}{100 Kernel (g) } & RHRG 6083 X KDG 209 & $3.88 * *$ & $\mathrm{~A}$ & A & \multirow{3}{*}{1.956} \\
\hline & RHRG 1225 X RTNG 29 & $3.34 * *$ & A & A & \\
\hline & K.GAURAV X ICG 2630 & $2.39 *$ & $\mathrm{G}$ & $\mathrm{A}$ & \\
\hline \multirow[t]{3}{*}{ Shelling $(\%)$} & RHRG 6083 X TAG 24 & $5.45 * *$ & $\mathrm{~A}$ & $\mathrm{~A}$ & \multirow{3}{*}{1.090} \\
\hline & RHRG 1225 X ICG 2630 & $3.16^{* *}$ & $\mathrm{~A}$ & $\mathrm{~A}$ & \\
\hline & K.GAURAV X JL 777 & $2.99 * *$ & A & $\mathrm{A}$ & \\
\hline \multirow[t]{3}{*}{ Sound mature kernel (\%) } & RHRG 6083 X ICG 2630 & $3.51 * *$ & A & A & \multirow{3}{*}{1.394} \\
\hline & RHRG 1225 X KDG 209 & $2.51 *$ & A & $\mathrm{A}$ & \\
\hline & TG 37A X TAG 24 & 1.52 & A & $\mathrm{A}$ & \\
\hline \multirow[t]{3}{*}{ Days to Maturity } & K.GAURAV X KDG 209 & $-4.97 * *$ & $\mathrm{P}$ & $\mathrm{P}$ & \\
\hline & K.GAURAV X RTNG 29 & $-3.97 * *$ & $\mathrm{P}$ & $\mathrm{A}$ & 1.732 \\
\hline & RHRG 1225 X JL 777 & $-3.85 * *$ & $\mathrm{~A}$ & $\mathrm{P}$ & \\
\hline Oil content $(\%)$ & K.GAURAV X RTNG 29 & $3.79 * *$ & A & $\mathrm{G}$ & \\
\hline & RHRG 6083 X ICG 2630 & $3.40 * *$ & A & $\mathrm{A}$ & 0.915 \\
\hline & TG 37A X RTNG 29 & $3.38 * *$ & $\mathrm{P}$ & $\mathrm{G}$ & \\
\hline Protein content $(\%)$ & K.GAURAV X TAG 24 & $2.09 *$ & A & $\mathrm{A}$ & \\
\hline & K.GAURAV X RTNG 29 & 1.28 & A & $\mathrm{A}$ & 1.106 \\
\hline & K.GAURAV X KDG 209 & 1.01 & $\mathrm{~A}$ & $\mathrm{~A}$ & \\
\hline
\end{tabular}

* Significant at 5 per cent, ** Significant at 1 per cent

$\mathrm{G}=$ Good parent having significant GCA effects in desirable direction; $\mathrm{A}=$ Average parent having either positive or negative but non-significant GCA effects; P = Poor parent having significant GCA effects in undesirable direction 
These results were in accordance with the findings of Sangha et al., (1990) for plant height.

The crosses exhibiting higher per se performance and significant desirable sca effects for various traits involved in all possible combinations viz., good $\mathrm{X}$ good, good $X$ average, good $X$ poor, average $X$ good, average $\mathrm{X}$ average, average $\mathrm{X}$ poor, poor $\mathrm{X}$ good, poor $\mathrm{X}$ average and poor $\mathrm{X}$ poor combining parents. Thus, crosses exhibiting high sca effects did not always involved parents with high gca effects. It may be suggested that inter allelic interaction were also important for these characters. Similar results were also reported by Savithramma et al., (2010). The performances of selected best three crosses for each character in related parameters are presented in Table 4. The crosses RHRG 6083 X RTNG 29 (-1.07), RHRG 1225 X KDG 209 (-0.67) and Konkan Gaurav X TAG $24(-0.63)$ were the best superior combinations for early flowering with the average performance of general combining ability of all the parents.

The crosses with high sca effects for plant height were in general combinations of parents with average $X$ good, average $X$ average and average $X$ poor gca effects. This was represented in best three hybrids for plant height viz., Konkan Gaurav X ICG 2630 (AxG), RHRG 6083 X KDG 209 (AxA) and TG 37A X TAG 24 (AxP).

The best specific combiner for number of primary branches plant ${ }^{-1}$ were RHRG $1225 \mathrm{X}$ ICG 2630, Konkan Gaurav X TAG 24 and TG 37A X JL 777. Top three hybrids viz., RHRG 6083 X TAG 24 (3.82), RHRG 6083 X JL 777 (3.59) and Konkan Gaurav X ICG $2630\left(3.43^{* *}\right)$ were identified as desirable specific combinations for number of pods plant $^{-1}$. All these three crosses were found to be the best general combiners with GxA, GxA and AxA performances respectively. The hybrids TG 37A X KDG 209, Konkan Gaurav X TAG 24 and RHRG 6083 X RTNG 29 topped the list of best performing hybrids for number of kernels pod $^{-1}$. The pre-dominance of sca variance for total number of seeds was also reported by Rudraswamy et al., (2001).

The cross RHRG 6083 X TAG 24 (3.10) exhibited highest positive significant sca effect for dry pod yield plant ${ }^{-1}$ followed by Konkan Gaurav X KDG 209 (2.37) and RHRG 6083 X RTNG 29 (2.23) crosses. These three crosses were found to be the best combinations involving good $\mathrm{X}$ average, average $\mathrm{X}$ average and good $\mathrm{X}$ average general combiner parents and also exhibited high mean performance and high heterotic potential for dry pod yield plant ${ }^{-1}$. This could be attributed to the involvement of nonadditive gene action in the inheritance of pod yield. These three crosses were also found as a good combiner parents for dry haulm yield plant $^{-1}$ with high mean performance and high heterotic potential. Similar results have been reported by Savithramma et al., (2010). Non additive effects were predominant in the expression of pod yield plant $^{-1}$ was also reported by Shoba et al., (2010), Gor et al., (2013) and Prabhu et al., (2014).

The hybrids RHRG 6083 X KDG 209 (3.88), RHRG 1225 X RTNG 29 (3.34) and Konkan Gaurav X ICG 2630 (2.39) were found top three performing for 100 kernel weight.

The best performing specific combiners for shelling percentage were RHRG 6083 X TAG 24 (5.45) followed by RHRG 1225 X ICG 2630 (3.16) and Konkan Gaurav X JL 777 (2.99) with average general combining ability. Whereas, RHRG 6083 X ICG 2630 (3.51), RHRG 1225 X KDG 209 (2.51) and TG 37A X TAG 24 (1.52) were observed to be the best specific combinations for sound mature kernels. These results are comparable with the 
work done by Varman, (2000) and Manoharan, (2001) for shelling percentage and by Varman and Raveendran (1994) for sound mature kernels.

The cross Konkan Gaurav X RTNG 29 (3.79) exhibited highest positive significant sca effect for oil content followed by RHRG 6083 X KDG 209 (3.40) and TG 37A X RTNG 29 (3.38) crosses. These three crosses were found to be the best combinations involving average $X$ good, average $X$ average and poor $\mathrm{X}$ good general combiner parents indicating the involvement of non-additive gene action in the inheritance of oil content also.

The crosses Konkan Gaurav X TAG 24 (2.09), Konkan Gaurav X RTNG 29 (1.28) and Konkan Gaurav X KDG 209 (1.01) were found best specific combinations for protein content.

These findings suggested that epistasis may be responsible for manifestation of these characters. Estimates of gca and sca components of variances revealed the importance of additive gene action and nonadditive gene action (John and Reddy, 2015). Skyes and Michaels (1986) reported additive gene action for oil per cent. Contrary to this, Venkateswarlu et al., (2007), and Ganesan et al., (2010) reported non-additive gene action for oil per cent.

In general, the crosses showing desirable sca effects for dry pod yield plant ${ }^{-1}$ also had high sca effects for yield contributing characters viz. plant height $(\mathrm{cm})$, number of pods plant ${ }^{-1}$, dry haulm weight plant $^{-1}$ (g) 100 kernel weight $(\mathrm{g})$, shelling $(\%)$, oil content (\%). Most of the crosses exhibiting desirable sca effects involved parents with high and low gca effects indicating the influence of nonadditive gene interaction in these crosses. Hence parents of these crosses can be utilized for biparental mating or reciprocal recurrent selection programme for developing superior varieties with high yield. Whereas crosses with higher sca and having both parents with good gca effects could be exploited by pedigree method to yield transgressive segregants.

\section{Acknowledgement}

The authors are highly thankful to the authorities of AICRP-G, Project, Agricultural Research Station, Shirgaon for providing necessary facilities to undertake this study.

\section{References}

Cockerham, C.C. 1961. Implication of genetic variances in a hybrid breeding programme. Crop Sci., 1: 47-52.

Ganesan, K.N., Paneerselvam, R. and Manivannan, N. 2010. Identification of crosses and good combiners for developing new genotypes in groundnut (Arachis hypogaea L.). Electronic Journal of Plant Breeding, 1(2): 67172.

Gor, H.K., Dhaduk L.K. and Lata R. 2013. Heterosis and inbreeding depression for pod yield and its components in groundnut (Arachis hypogaea L.). Electronic Journal of Plant Breeding. 3(3): 868-874.

John, K. and Reddy, P.R. 2015. Genetic analysis of oil and protein contents in groundnut (Arachis hypogaea L.). Int. J. Curr. Res. Biosci. Plant Biol. 2(5): 5668.

Kempthorne, 1957. An introduction to Genetic statistics. John Wiley and son Inc., New York. 545.

Manoharan, V., 2001, Gene action for shelling out turn in bunch groundnut. In: National symposium pulses and oilseeds for sustainable agriculture. Directorate of Research, TNAU, Coimbatore. 56.

Prabhu R., Manivannan, N., Mothilal, A. and 
Ibrahim, S.M. 2014. Combining ability analysis for yield and its component traits in groundnut (Arachis hypogaea L.) Electronic Journal of Plant Breeding. 5(1): 30-37.

Rudraswamy, P., Nehru, S.D. and Kulkarni, R.S. 2001. Combining ability studies on groundnut. Mysore J. Agric. Sci. 35(3): 193-202.

Sangha, A.S., Labana, K.S. and Mohinder Singh, 1990. Genetic analysis in a cross of runner and bunch groundnut types. Crop Improv. 17(2): 186 - 187.

Savithramma, D.L., Rekha, D. and Sowmya, H.C. 2010. Combining ability studies for growth and yield related traits in groundnut (Arachis hypogaea L.). Electronic Journal of Plant Breeding. 1(4): 1010-1015.

Shoba, D. N., Manivannan and Vindhiyavarman, P. 2010. Gene effects of pod yield and its components in three crosses of groundnut (Arachis hypogaea L.). Electronic Journal of Plant
Breeding. 1(6):1415-1419.

Sykes, E. E. and Michaels, T. E. 1986. Combining Ability of Ontario-Grown Peanuts (Arachis hypogaea L.) for Oil, Fatty Acids, and Taxonomic Characters. Peanut Science. 13(2): 93-97.

Sprague, G. F. and Tatum, L. A. 1942. General vs. specific combining ability in single hybrids of corn. J. Amer. Soc. Agron. 34: 923-932.

Varman, V.P. and Raveendran, T.S., 1994, Line X Tester analysis of combining ability in groundnut. Madras Agric. J. 81(10): 529-532.

Varman, P., 2000, combining ability estimates in groundnut (Arachis hypogaea L). Madras Agric. J. 87(7-9): 462-466.

Venkateswarlu, O., Reddy, K.R., Reddy, P.V., Vasanthi, R.P., Reddy, K.H.P. and Reddy, N.P.E. 2007. Heterosis for physiological and yield traits in groundnut (Arachis hypogaea L.). Legume Res. 30: 250-255.

\section{How to cite this article:}

Waghmode, B.D., A.B. Kore, V.C. Navhale, N.G. Sonone and Thaware, B.L. 2017. Genetic Analysis of Promising Crosses and Good Combiners for Developing New Genotypes in Groundnut (Arachis hypogaea L.). Int.J.Curr.Microbiol.App.Sci. 6(7): 324-331. doi: https://doi.org/10.20546/ijcmas.2017.607.038 